\title{
Biosorption of Hexavalent Chromium by Pseudomonas aeruginosa Strain ANSC: Equilibria Isothermic, Kinetic and Thermodynamic Studies
}

\author{
Ojiagu, Kingsley David ${ }^{1, *}$, Odibo, Frederick John Chidi $^{1}$, Ojiagu, Nnenna Chinelo ${ }^{1}$, \\ Agu, Kingsley Chukwuebuka ${ }^{1}$, Okafor, Arthur Chinedu ${ }^{2}$ \\ ${ }^{1}$ Department of Applied Microbiology and Brewing, Nnamdi Azikiwe University, Awka, Nigeria \\ ${ }^{2}$ Department of Microbiology, Renaissance University, Enugu, Nigeria
}

Copyright $(2018$ by authors, all rights reserved. Authors agree that this article remains permanently open access under the terms of the Creative Commons Attribution License 4.0 International License

\begin{abstract}
Pseudomonas aeruginosa strain ANSC, a non-genetically modified bacterial strain isolated from soil was used to study and evaluate biosorption potentials for hexavalent chromium $(\mathrm{Cr}[\mathrm{VI}])$ from aqueous solution. Living, heat-killed, and permeabilised cells were all used and found to be capable of reducing and sorbing $\mathrm{Cr}(\mathrm{VI})$. The influences of initial $\mathrm{Cr}(\mathrm{VI})$ ion concentration (50-150 $\mathrm{mg} / \mathrm{L})$, contact time ( $2 \mathrm{~h}, 10 \mathrm{~min}$ intervals), $\mathrm{pH}(2-8)$, temperature $\left(30-60^{\circ} \mathrm{C}\right)$ and biosorbent mass $(1.0-5.0 \mathrm{~g} / \mathrm{l})$ were reported. Adsorption of $\mathrm{Cr}(\mathrm{VI})$ is highly $\mathrm{pH}$ - and temperature-dependent, and the results indicate that the optimum $\mathrm{pH}$ and temperature for removal were found to be 2 and $60^{\circ} \mathrm{C}$ respectively. The hexavalent chromium biosorption equilibrium could be better described by Langmuir isotherm than it could by Freundlich isotherm. A comparison of kinetic models applied to the adsorption of $\mathrm{Cr}(\mathrm{VI})$ ions onto the biosorbents was evaluated for the pseudo first-order, pseudo second-order, and intra-particle diffusion kinetic models. Results show that the pseudo second-order kinetic model was evidenced to correlate better the experimental data. The rate of hexavalent chromium adsorption increased following permeabilisation of the outer and/or cytoplasmic membrane by surfactants such as Triton X100, Tween 80, toluene, sodium deoxycholate and sodium dodecyl sulphate. The adsorption process has been found endothermic, and thermodynamic parameters of Gibb's free energy $\left(\Delta G^{\circ}\right)$, change in enthalpy $\left(\Delta H^{\circ}\right)$ and change in entropy $\left(\Delta S^{\circ}\right)$ were calculated. Pseudomonas aeruginosa strain ANSC evidenced an effective biosorbent for the removal of hexavalent chromium in aqueous form.
\end{abstract}

Keywords Pseudomonas aeruginosa, Adsorption, Kinetic, Isotherm, Thermodynamic

\section{Introduction}

Increasing industrialization and technological expansion, rapid urbanization, increased energy utilization and waste generation from domestic and industrial sources have ravaged the environment by discharge of industrial and domestic wastes laden with heavy metals. And contamination of soil and water bodies by organic pollutants and toxic metals has been increased in the past few years due to industrialization, intensive agriculture and anthropogenic activities [1].

Chromium and its compounds are widely used in industries. Hexavalent chromium is present in effluents from electroplating, paint, pigment, cement, mining, dyeing, leather tanning, fertiliser and photography industries. Hexavalent chromium is toxic to humans. Removal of heavy metals from metal-ladened wastewater is often achieved by physico-chemical processes. Physico-chemical processes in use for heavy metal removal from wastewater include precipitation, coagulation, chemical reduction processes, ion exchange, membrane processes such as ultrafiltration, electrodialysis and reverse osmosis, and adsorption [2]. These conventional treatment techniques have reportedly become less effective, more expensive and intensive, requiring highly skilled labour and running energy.

Microbial cells interact with chromium at different levels from the cell wall and periplasm to the cytoplasm and cell organelles [3]. Microorganisms require detecting and regulating intracellular levels of chromium through homeostatic systems that maintain balance between the incorporation, expulsion, and arrest of metal [3].

Therefore, biosorption, the process of attracting various chemical species by biomass (live or dead) through physicochemical mechanisms as adsorption or ion exchange, has presented a more efficient and 
environmental-friendly technology to remediate heavy metals. In this current study, live, heat-killed and permeabilised cells of hexavalent chromium tolerant microbe were used to reduce and sorb $\mathrm{Cr}(\mathrm{VI})$ from aqueous solution. Also, influences of initial metal concentration of $\mathrm{Cr}(\mathrm{VI})$, contact time, $\mathrm{pH}$, temperature and biosorbent dosage were evaluated while correlating the process equilibria adsorption isotherm, kinetics and thermodynamics.

\section{Methods}

\subsection{Screening of Microorganism Showing Resistance to Hexavalent Chromium}

Chromate resistant bacterium was isolated from soil with a history of previous contained chemical discharge. The bacterial isolate was screened for tolerance towards hexavalent chromium. The bacterium was grown on Petri dishes containing Luria-Bertani (LB) agar supplemented with $500 \mathrm{mg} / \mathrm{L}$ of $\mathrm{K}_{2} \mathrm{Cr}_{2} \mathrm{O}_{7}$. The $\mathrm{pH}$ of the medium was maintained at 5.3. Plates were incubated at $37^{\circ} \mathrm{C}$ for 3 days.

\subsection{Identification of Isolate by $16 \mathrm{~S}$ rRNA Gene Sequence}

Genomic DNA of the chromate-tolerant bacterial isolate was isolated, and gene fragments specific to the highly variable region of the bacterial 16S rRNA gene amplified by polymerase chain reaction (PCR) (Macrogen Inc., Seoul, Korea). The primers 27F 5' (AGA GTT TGA TCM TGG CTC AG) 3' and 1492R 5' (TAC GGY TAC CTT GTT ACG ACT T) 3' were used for the PCR. The PCR reaction was performed with $20 \mathrm{ng}$ of genomic DNA as the template in a $30 \mu \mathrm{L}$ reaction mixture by using an EF-Taq (SolGent, Korea) as follows: activation of $T a q$ polymerase at $95^{\circ} \mathrm{C}$ for 2 minutes, 35 cycles of $95^{\circ} \mathrm{C}$ for 1 minute, $55^{\circ} \mathrm{C}$, and $72^{\circ} \mathrm{C}$ for 1 minute each were performed, finishing with a 10 -minute step at $72^{\circ} \mathrm{C}$. The amplification products were purified with a multiscreen filter plate (Millipore Corp., Bedford, MA, USA). Sequencing reaction was performed using a PRISM BigDye Terminator v3.1 Cycle sequencing Kit. The DNA samples containing the extension products were added to Hi-Di formamide (Applied Biosystems, Foster City, CA). The mixture was incubated at $95^{\circ} \mathrm{C}$ for 5 minutes, followed by 5 minutes on ice and then analyzed by ABI Prism 3730XL DNA analyzer (Applied Biosystems, Foster City, CA). The homology of the $16 \mathrm{~S}$ rRNA gene sequences was checked with the 16S rRNA gene sequences of other organisms that had already been submitted to GenBank database using the BLASTN (http://www.ncbi.nih.gov/BLAST/) algorithm

\subsection{Reduction of $\mathrm{Cr}$ (VI) by Living and Permeabilised Cells of Isolate}

Efficiency of $\mathrm{Cr}(\mathrm{VI})$ reduction was examined by living and permeabilised cells of isolate. For live cells, isolate was grown overnight in LB broth in the presence of $10 \mathrm{mg} / \mathrm{L} \mathrm{K}_{2} \mathrm{Cr}_{2} \mathrm{O}_{7}$. The pre-cultures were used for inocula into different cultures containing 0, 100, 200, 300, 400, 500 and $600 \mathrm{mg} / \mathrm{L}$ of $\mathrm{K}_{2} \mathrm{Cr}_{2} \mathrm{O}_{7}$. The different $\mathrm{Cr}(\mathrm{VI})$-containing broth cultures were incubated in an orbital shaker at 150 $\mathrm{rpm}, 37^{\circ} \mathrm{C}$. At different times $(0,24,48,72,96$, and $120 \mathrm{~h})$, aliquots were harvested in order to measure absorbances at $600 \mathrm{~nm}$ and $540 \mathrm{~nm}$ for growth and $\mathrm{Cr}(\mathrm{VI})$ reduction respectively. Hexavalent chromium was quantified by employing the $S$-diphenylcarbazide (DPC) method [5].

For permeabilised cells, cultures of isolate were grown for five days in an orbital shaker at $37^{\circ} \mathrm{C}$, harvested, and washed twice with sterile tri-deionized water, and suspended in $0.1 \mathrm{M}$ potassium phosphate buffer $(\mathrm{pH} 7.0)$. The suspended biomass was treated with $0.5 \% \mathrm{v} / \mathrm{w}$ triton $\mathrm{X}-100,0.5 \% \mathrm{v} / \mathrm{w}$ tween $80,0.5 \% \mathrm{v} / \mathrm{w}$ toluene, $0.5 \% \mathrm{w} / \mathrm{w}$ sodium deoxycholate and $0.5 \% \mathrm{w} / \mathrm{w}$ sodium dodecyl sulphate, and vortexed for $30 \mathrm{~min}$ to achieve cell permeabilisation. Permeabilised cell suspensions ( 2 wet $g$ ) were then added into $20 \mathrm{~mL}$ of $100 \mu \mathrm{g} / \mathrm{mL}$ solutions of $\mathrm{K}_{2} \mathrm{Cr}_{2} \mathrm{O}_{7}$, and incubated for $5 \mathrm{~h}$ at $37^{\circ} \mathrm{C}$ [6]. The samples were filtered. The filtrates containing the residual $\mathrm{Cr}(\mathrm{VI})$ solution were evaluated colourimetrically with absorbance read at 540nm using the DPC method.

\subsection{Biosorption Studies Using Heat-killed Biomass of Isolate}

Adsorption of hexavalent chromium onto heat-killed biomass of isolate was investigated in a batch system. After 5 days of growth in LB broth, the biomass was recovered by centrifugation at 3,000 rpm for $10 \mathrm{~min}$. The recovered biomass was washed as above and heat-killed at $80^{\circ} \mathrm{C}$ for $24 \mathrm{~h}$. Solutions of chromate containing 50-150 mg/L were prepared using sterile deionized water. The concentrations of chromate studied were prepared from stock solutions. Adsorption experiments were performed by stirring magnetically at $150 \mathrm{rpm}$, at $30^{\circ} \mathrm{C}$ for $2 \mathrm{~h}$. The adsorption volume was $20 \mathrm{~mL}$, and a $1-5 \mathrm{~g}$ biosorbent dosage was used. After centrifugation, the amount of unadsorbed $\mathrm{Cr}$ (VI) in the supernatant solutions was measured. The amount of $\mathrm{Cr}(\mathrm{VI})$ ion adsorbed onto the biomass at time, $q_{\mathrm{t}}$, was obtained by using the following expression,

$$
q t=\frac{V(C o-C t)}{W}
$$

Metal ion removal percentage was calculated as follows:

$$
\text { Removal } \%=\frac{(C o-C t)}{C o} \times 100
$$

where $C_{0}$ and $C_{\mathrm{t}}$ are the initial concentration and concentration at a particular time, $t$, of metal ion solution 
$(\mathrm{mg} / \mathrm{L})$ respectively, $V$ is the volume of the chromate solution (L), and $W$ is the weight of the bacterial biomass $(g)$ [7].

The effect of contact time at varying temperature level (i.e., 30, 40, 50 and $60{ }^{\circ} \mathrm{C}$ ) on adsorption capacity was evaluated. Also, the effect of $\mathrm{pH}$ of the solution on the adsorption capacity of the bacterial biomass was investigated $(2.0-8.0)$ at $30^{\circ} \mathrm{C}$. Batch experiments were also conducted using different amounts of biosorbent (1.0 and $5.0 \mathrm{~g}$ biomass weight) at $\mathrm{pH} 2.0$ and $30^{\circ} \mathrm{C}$. To determine the effect of initial concentrations of $\mathrm{Cr}(\mathrm{VI})$ on the adsorption rate and capacity of the adsorbent, concentration was varied between 50 and $150 \mathrm{mg} / \mathrm{L}$ in the adsorption medium at $\mathrm{pH}$ 5.0. For each adsorption experiment, replicate means were reported.

\section{Results and Discussion}

\subsection{Isolation and Identification of Chromate Tolerant Bacterial Isolate}

Microorganism was grown on LB agar plates containing $500 \mathrm{mg} / \mathrm{L}$ of $\mathrm{K}_{2} \mathrm{Cr}_{2} \mathrm{O}_{7}$. Colonies isolated grew rapidly within three days of incubation at $37^{\circ} \mathrm{C}$. Colonies were usually erose, convexed and rough with approximately 4 $\mathrm{mm}$ in diameter, and they were fast growing at such elevated concentration of $\mathrm{K}_{2} \mathrm{Cr}_{2} \mathrm{O}_{7}$. In similar works, Camargo and coworkers [8] isolated some chromium resistant bacteria that can tolerate or reduce $\mathrm{Cr}(\mathrm{VI})$ at concentrations of $1500-2500 \mathrm{mg} / \mathrm{L}$; and Polti et al. [9] isolated actinomycete strains of Streptomyces spp. and Amycolatopsis spp. capable of tolerating hexavalent chromium concentration of up to $17 \mathrm{mM}\left(\mathrm{K}_{2} \mathrm{Cr}_{2} \mathrm{O}_{7}\right)$ i.e. ca $5,000 \mathrm{mg} / \mathrm{L}$. The isolate was identified using the $16 \mathrm{~S}$ rRNA gene sequence analysis (Table 1). Isolate showed 99\% sequence identity with Pseudomonas aeruginosa strain ANSC.

Table 1. Identification of chromium(VI)-reducing bacterial isolate by 16S rRNA gene sequence analyses

\begin{tabular}{|c|c|c|c|}
\hline Organism & $\begin{array}{c}\text { Accession } \\
\text { number }\end{array}$ & $\begin{array}{c}\text { E } \\
\text { value }\end{array}$ & $\begin{array}{c}\text { Identity } \\
(\%)\end{array}$ \\
\hline $\begin{array}{c}\text { Pseudomonas aeruginosa } \\
\text { ANSC }\end{array}$ & GU296674.1 & 0.0 & 99 \\
\hline
\end{tabular}

\subsection{Effect of Chromium(VI) Concentration on $\mathrm{Cr}(\mathrm{VI})$ Removal and Growth}

The removal of $\mathrm{Cr}(\mathrm{VI})$ by Pseudomonas aeruginosa ANSC was examined using live cells, and the effect of varying concentrations of $\mathrm{Cr}(\mathrm{VI})\left(\right.$ as $\left.\mathrm{K}_{2} \mathrm{Cr}_{2} \mathrm{O}_{7}\right)$ on bacterial growth was examined as well. $\mathrm{Cr}(\mathrm{VI})$ concentrations of $100-600 \mathrm{mg} / \mathrm{L}$ were used to examine the $\mathrm{Cr}(\mathrm{VI})$ removal and effect on growth. The bacterial cells (ca. $2.06 \times 10^{8}$ $\mathrm{cfu} / \mathrm{mL}$ ), which were cultured in $100 \mathrm{~mL}$ LB broth containing $10 \mathrm{mg} / \mathrm{L} \mathrm{Cr}(\mathrm{VI})$, under orbital shaking at $150 \mathrm{rpm}$ at $37^{\circ} \mathrm{C}$, were used to seed $25 \mathrm{~mL}$ LB broth containing 100, 200, 300, 400, 500 and $600 \mathrm{mg} / \mathrm{L} \mathrm{K}_{2} \mathrm{Cr}_{2} \mathrm{O}_{7}$. Triplicate assays were examined for both growth and $\mathrm{Cr}(\mathrm{VI})$ removal/reduction parameters at a $24-\mathrm{h}$ interval for $120 \mathrm{~h}$. The percentage amount of $\mathrm{Cr}(\mathrm{VI})$ removed was determined.

Figure 1 shows the percentage $\mathrm{Cr}(\mathrm{VI})$ removed by $P$. aeruginosa ANSC under varying concentrations of $\mathrm{Cr}(\mathrm{VI})$ against time, with Figure 2 showing the effect of $\mathrm{Cr}(\mathrm{VI})$ on $P$. aeruginosa ANSC growth against time. Under 100 and $200 \mathrm{mg} / \mathrm{L}$ of chromate, $P$. aeruginosa evidenced a $95.87 \%$ and $78.41 \% \mathrm{Cr}(\mathrm{VI})$ removal respectively by $48 \mathrm{~h}$. However, by $72 \mathrm{~h}$ [at 100 and $200 \mathrm{mg} / \mathrm{L}$ ] the $\mathrm{Cr}(\mathrm{VI})-\mathrm{DPC}$ assay produced no resultant colour complex with an indication of complete removal of $\mathrm{Cr}(\mathrm{VI})$ from the broth. Under $300 \mathrm{mg} / \mathrm{L}$ of chromate, P. aeruginosa ANSC removed nearly all residual chromate $(96.03 \%)$ by $120 \mathrm{~h}$ of incubation. Under 400,500 and $600 \mathrm{mg} / \mathrm{L}$ of chromate, however, P. aeruginosa ANSC evidenced a steady increase towards removal of $\mathrm{Cr}(\mathrm{VI})$, with the bacterium recording the least percentage $\mathrm{Cr}(\mathrm{VI})$ removal of $41.53 \%$ under $600 \mathrm{mg} / \mathrm{L}$ of chromate at $120 \mathrm{~h}$. Similar outcomes were reported by Dey and Paul [10] using whole cells of Arthrobacter sp. SUK 1205 isolated from metalliferous chromite mine. Batch cultures of Arthrobacter sp. under $100 \mu \mathrm{M}$ of $\mathrm{Cr}(\mathrm{VI})$ were used to observe effect and outcome of $\mathrm{Cr}(\mathrm{VI})$ reduction and growth inhibition. Complete reduction of $100 \mu \mathrm{M} \mathrm{Cr}(\mathrm{VI})$ was achieved in $48 \mathrm{~h}$ of incubation at $35^{\circ} \mathrm{C}$ under continuous shaking at $120 \mathrm{rpm}$ [10]. Relative trends in chromate removal/reduction were also reported by Pattanapipitpaisal et al. [11] using Microbacterium liquefaciens.

For effect on growth, $P$. aeruginosa ANSC proportionately showed increase in cell density with decreasing influence of chromate concentration (Figure 2). Under 100,200 and $300 \mathrm{mg} / \mathrm{L}$ chromate, $P$. aeruginosa ANSC grew exponentially within the initial $48 \mathrm{~h}$. Relatively, all residual $\mathrm{Cr}(\mathrm{VI})$ was removed by $48 \mathrm{~h}$ of incubation under 100,200 and $300 \mathrm{mg} / \mathrm{L}$ of $\mathrm{Cr}(\mathrm{VI})$ concentrations by the isolate. Dey and Paul [10] recorded similar result with respect to time for the removal of 100 $\mu \mathrm{M} \quad \mathrm{Cr}(\mathrm{VI})$. Also, initial cell densities were not significantly influenced by the isolate's $\mathrm{Cr}(\mathrm{VI})$ removal process with respect to control (without $\mathrm{Cr}[\mathrm{VI}]$ ), except for a slight decrease of initial cell density at $300 \mathrm{mg} / \mathrm{L} \mathrm{Cr}(\mathrm{VI})$ (Figure 2). Similar observations were reported by $\mathrm{Pal}$ and Paul [12] using chromate resistant bacteria isolated from serpentine soil. Further, under $600 \mathrm{mg} / \mathrm{L} \mathrm{Cr}(\mathrm{VI})$, however, initial cell density of $P$. aeruginosa ANSC was greatly retarded by higher $\mathrm{Cr}(\mathrm{VI})$ concentration. Therefore, the removal of hexavalent chromium from aqueous solution by $P$. aeruginosa ANSC is growth dependent. 


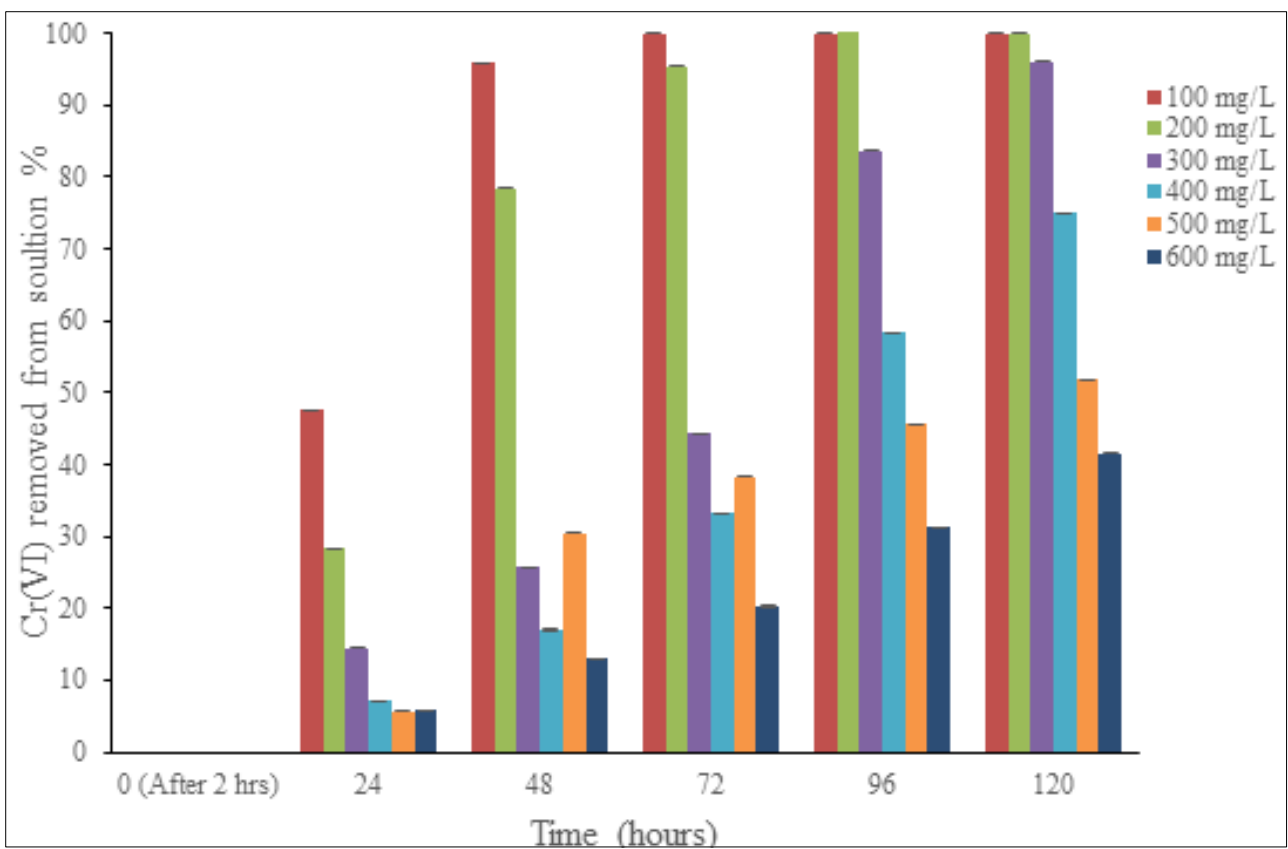

Figure 1. Removal of $\mathrm{Cr}(\mathrm{VI})$ as differing $\mathrm{K}_{2} \mathrm{Cr}_{2} \mathrm{O}_{7}$ concentrations in aqueous solution by $P$. aeruginosa ANSC. Error bars denote standard error

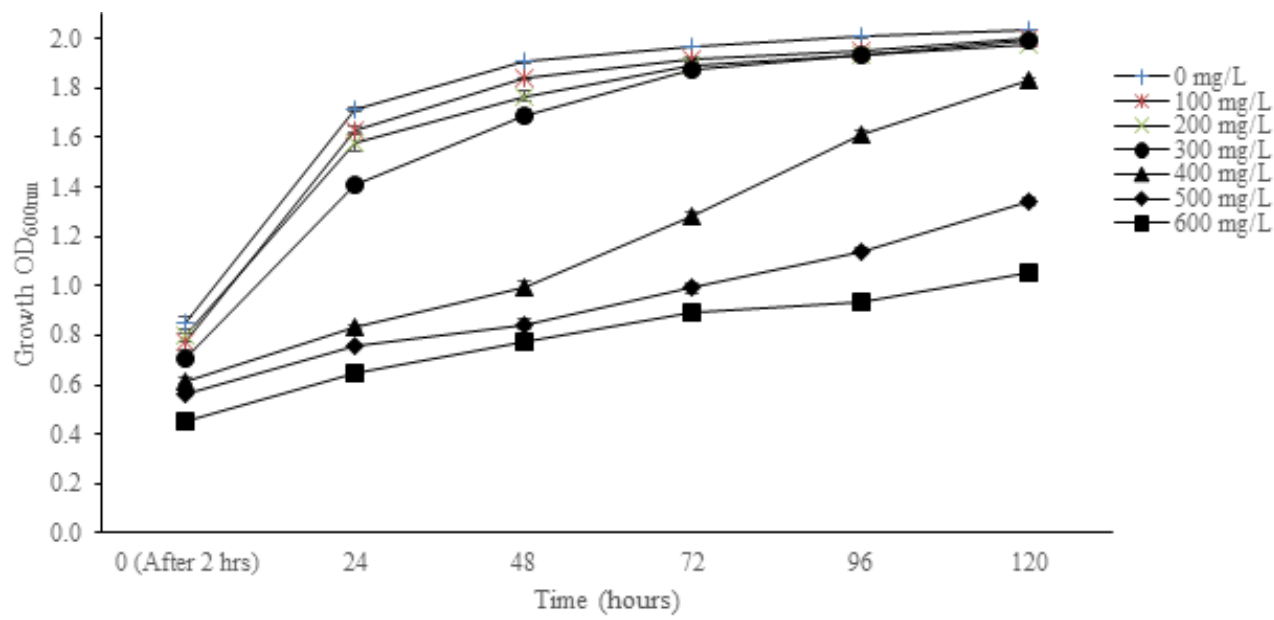

Figure 2. Growth of $P$. aeruginosa ANSC in the presence of different concentrations of $\mathrm{Cr}(\mathrm{VI})$. Error bars denote standard errors

\subsection{Adsorption by Permeabilised Cells}

Cells of $P$. aeruginosa ANSC were permeabilised using Triton X-100, tween 80 , toluene, sodium dodecyl sulphate (SDS) and sodium deoxycholate (SDC). Comparisons of $\mathrm{Cr}(\mathrm{VI})$ removal/uptake by permeabilised cells of the isolate were made against resting cells (control) of the isolate under same $\mathrm{Cr}(\mathrm{VI})$ concentration and conditions. It was observed that cell permeabilisation increased $\mathrm{Cr}(\mathrm{VI})$ removal/uptake, as Triton X-100 permeabilised cells removed $47 \%$ of residual chromate, and tween $8027 \%$, toluene $37 \%$, SDS $29 \%$ and SDC $31 \%$ (Figure 3) within $5 \mathrm{~h}$. This suggests an efficient intracellular mechanism of chromate uptake by $P$. aeruginosa ANSC. 


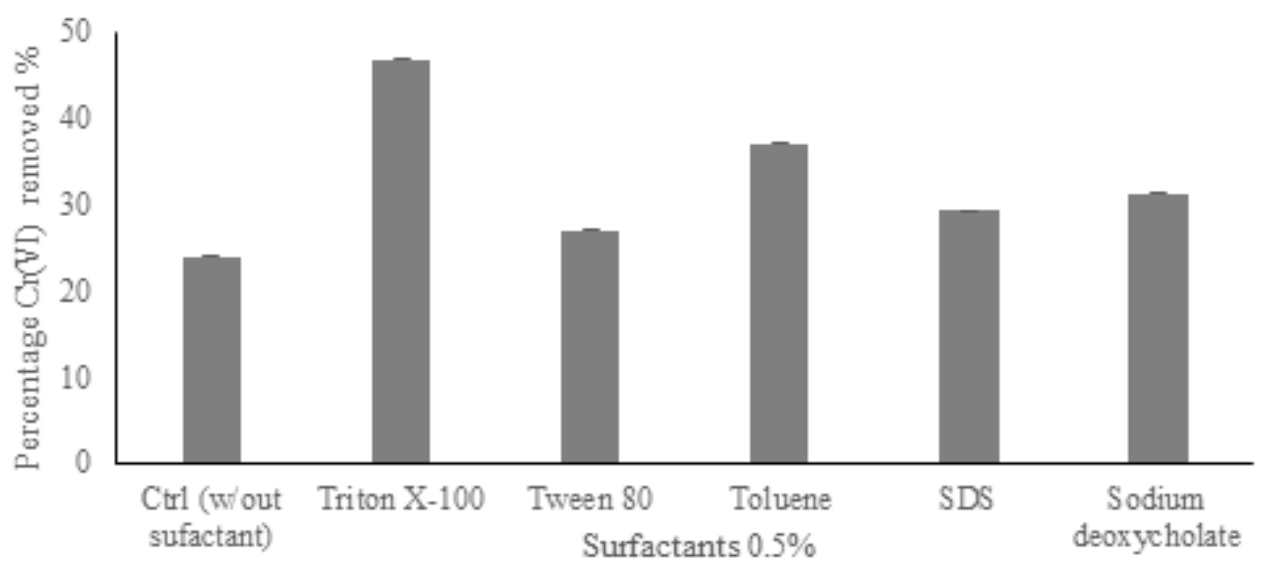

Figure 3. Permeabilized cell assays for $\mathrm{Cr}(\mathrm{VI})$ removal by $P$. aeruginosa ANSC at concentrations of $100 \mathrm{mg} / \mathrm{L}$ of $\mathrm{Cr}$ (VI)

\subsection{Adsorption Parameters}

\subsubsection{Effect of Contact Time}

The adsorption time of hexavalent chromium on heat-killed biosorbents of $P$. aeruginosa ANSC was investigated in 2 h. As seen in Figure 4, inclined initial gradients for the adsorption curves are observed for temperatures of 60 and $50^{\circ} \mathrm{C}$. Also, lesser heightened slopes for temperatures of 40 and $30^{\circ} \mathrm{C}$ are also observed. These indicate that the first uptake period of $\mathrm{Cr}(\mathrm{VI})$ is relatively rapid especially at higher temperatures of 50 and $60^{\circ} \mathrm{C}$. This may be due to the fact that at the beginning of the sorption process all the reaction sites are vacant, and hence the extent of removal is high [13]. And, more reaction sites are made easily accessible to $\mathrm{Cr}(\mathrm{VI})$ with proportional increase in temperature. Further, after a rapid first uptake, there was a transitionary phase in which the rate of uptake of $\mathrm{Cr}(\mathrm{VI})$ was gradual with uptake reaching almost a steady range. Therefore, the adsorption of hexavalent chromium by $P$. aeruginosa ANSC was carried out in two discrete levels, a relatively rapid level followed by a gradual phase.

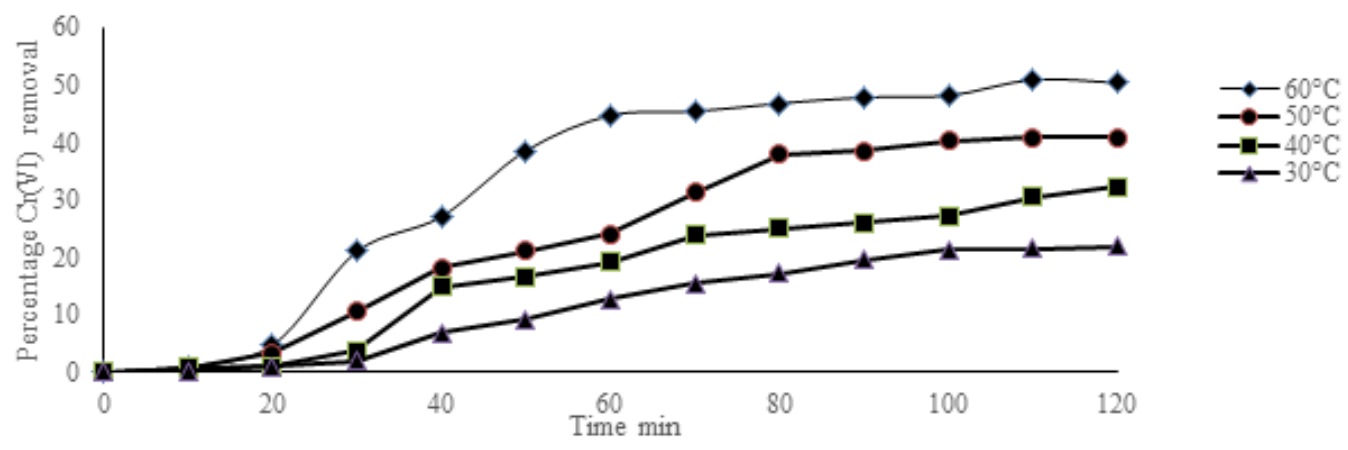

Figure 4. Adsorption time of hexavalent chromium onto dead biomass of $P$. aeruginosa ANSC. Adsorption conditions-initial concentration of $\mathrm{Cr}(\mathrm{VI}): 100 \mathrm{mg} / \mathrm{L}$; medium $\mathrm{pH}$ : 5.0; solution volume: $20 \mathrm{~mL}$; amount of adsorbent: $1 \mathrm{~g} / \mathrm{L}$; temperature: $30-60^{\circ} \mathrm{C}$

\subsubsection{Effect of $\mathrm{pH}$}

Adsorption is primarily influenced by the surface charge of the adsorbent and the degree of ionization of the adsorptive sites [14]. The effect of $\mathrm{pH}$ on the adsorption capacity of the heat-killed biomass of $P$. aeruginosa ANSC was studied using chromate under the $\mathrm{pH}$ range of 2.0-8.0. As seen in Figure 5, the removal efficiency of $\mathrm{Cr}(\mathrm{VI})$ improved with decreasing $\mathrm{pH}$ range, with $\mathrm{pH} 2$ and 3 showing the most efficient $\mathrm{pH}$ levels for $\mathrm{Cr}(\mathrm{VI})$ uptake. The $\mathrm{pH}$ value of the solution played a key role in $\mathrm{Cr}(\mathrm{VI})$ removal. Expectedly, the ability of sorbing $\mathrm{Cr}(\mathrm{VI})$ is related to the acidic surface functional groups of the adsorbents. At higher $\mathrm{pH}$ values, the $\mathrm{Cr}(\mathrm{VI})$ removal ability of the adsorbents is restricted by increasing acidic surface functional, as a result of the weak interactions between the adsorbents' rich carboxyl group and the anionic dichromate ions. At lower $\mathrm{pH}$ values, however, the acidic surface functional groups almost have no effect on the $\mathrm{Cr}(\mathrm{VI})$ removal by the adsorbents from aqueous solution. 


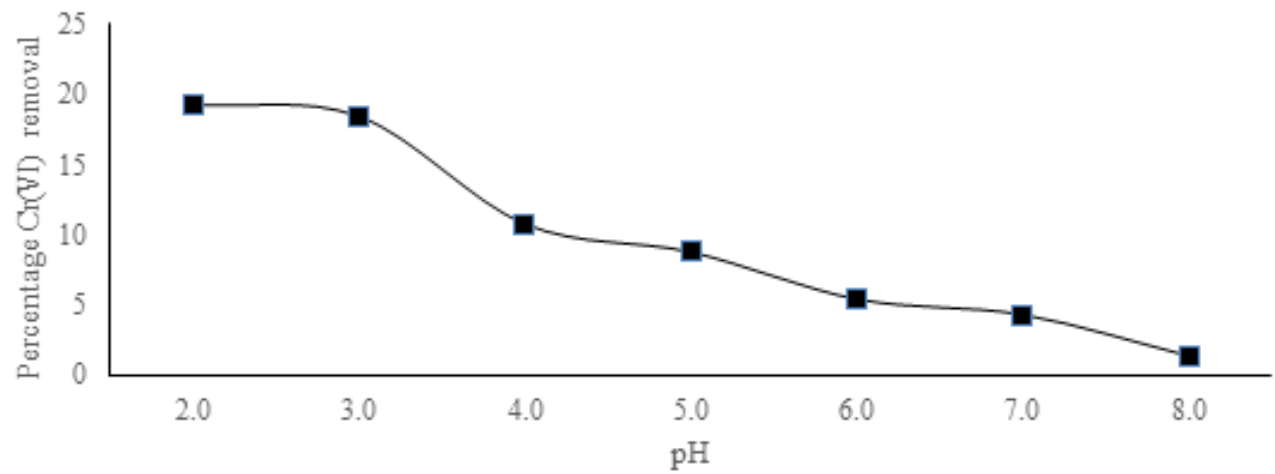

Figure 5. Effect of $\mathrm{pH}$ on the adsorption capacity of $P$. aeruginosa ANSC dried biomass for hexavalent chromium. Adsorption conditions-initial concentration: $100 \mu \mathrm{g} / \mathrm{ml}$; temperature: $30^{\circ} \mathrm{C}$; solution volume: $20 \mathrm{~mL}$; amount of biomass: $1.0 \mathrm{~g} / \mathrm{L}$; adsorption time:

\subsubsection{Effect of Adsorbent Dosage}

The reliance of hexavalent chromium adsorption on adsorbent dosage was investigated by varying the amount of adsorbents in the medium from 1.0 to $5.0 \mathrm{~g}$ while keeping other parameters such as initial concentration of $\mathrm{Cr}(\mathrm{VI})(100$ $\mathrm{mg} / \mathrm{L}), \mathrm{pH}(2.0)$, temperature $\left(30^{\circ} \mathrm{C}\right)$, stirring rate $(150 \mathrm{rpm})$ and contact time $(2 \mathrm{~h})$ constant. The removal efficiency of the adsorbent was enhanced with increasing adsorbent dosage (as seen in Figure 6). Therefore, the higher the dosage of adsorbents in the adsorption medium, the plentiful the availability of sorption sites for the $\mathrm{Cr}(\mathrm{VI})$ ions. Overall, the percentage $\mathrm{Cr}(\mathrm{VI})$ removed by dosage increased from 21 to $42 \%$ with an increase in adsorbent weight of 1.0 to $5.0 \mathrm{~g}$. As the adsorbent dose increased, surface area and available sites for $\mathrm{Cr}(\mathrm{VI})$ ions also increased. Therefore, better adsorption was recorded.

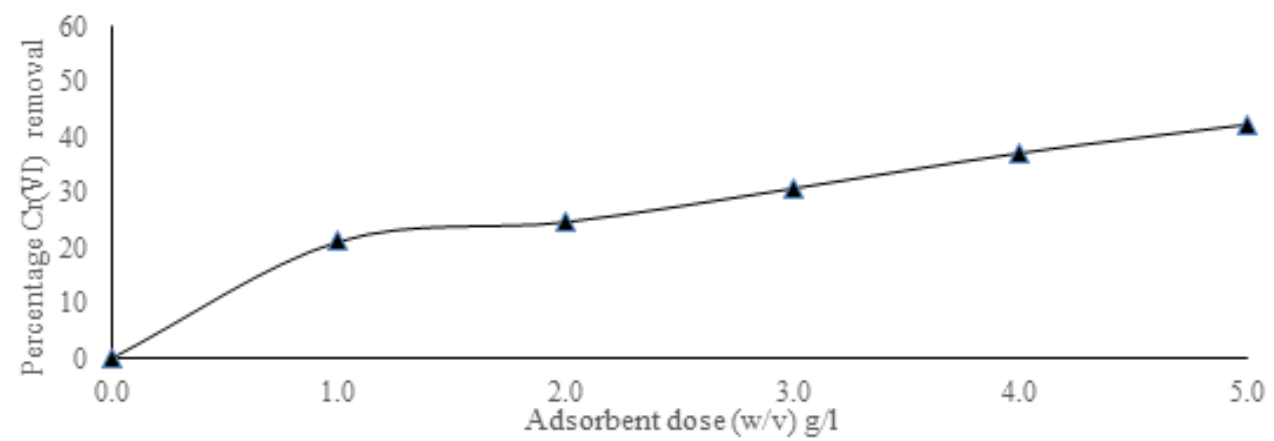

Figure 6. Effect of $P$. aeruginosa ANSC biomass dosage on hexavalent chromium adsorption. Adsorption conditions-initial concentration of $\mathrm{Cr}(\mathrm{VI}): 100 \mathrm{mg} / \mathrm{L}$; medium pH: 2.0; solution volume: $20 \mathrm{~mL}$; amount of adsorbent: 1.0-5.0 g/L; temperature: $30^{\circ} \mathrm{C}$.

\subsubsection{Effect of Initial Concentrations of $\mathrm{Cr}(\mathrm{VI})$ on the Adsorption Efficiency}

The initial concentration of adsorbate provides a key influence to overcoming resistances of all mass transfer of the adsorbate molecules between aqueous and solid phases [13]. The concentrations selected for the study were 50, 75, 100, 125 , and $150 \mathrm{mg} / \mathrm{L}$. As seen in Figure 7, removal increases with decreasing initial concentration of $\mathrm{Cr}(\mathrm{VI})$. The data showed that as the initial concentration of residual chromate increased from 50 to $150 \mathrm{mg} / \mathrm{L}$, the percentage adsorption decreased from 43 to $8 \%$. This is indicative of the dependence of $\mathrm{Cr}(\mathrm{VI})$ removal on adsorbate concentration.

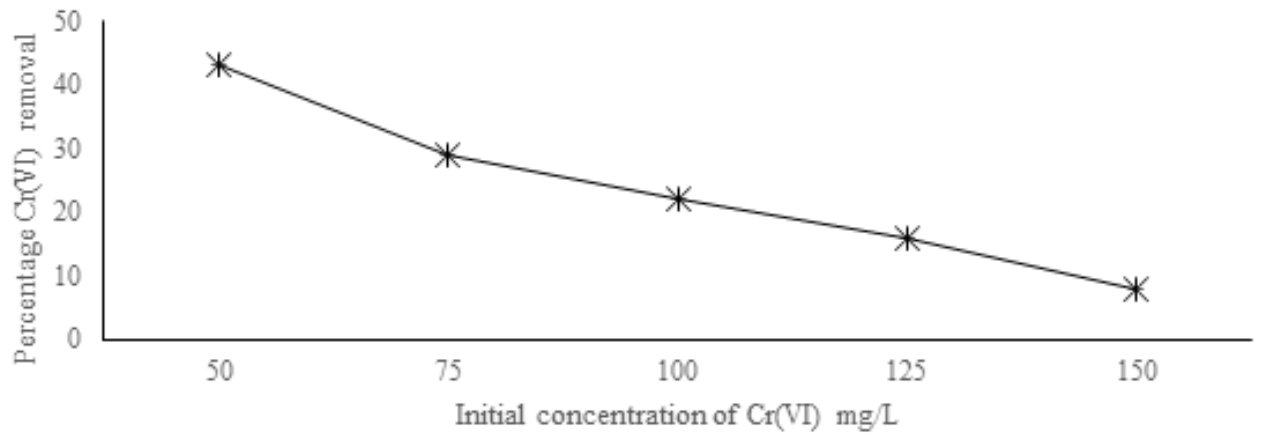

Figure 7. Effect of initial concentration of $\mathrm{Cr}(\mathrm{VI})$ on the adsorption capacity of $P$. aeruginosa ANSC dried biomass Adsorption conditions - initial concentration: $100 \mathrm{mg} / \mathrm{L}$; temperature: $30^{\circ} \mathrm{C}$; $\mathrm{pH} 2.0$; solution volume: $20 \mathrm{~mL}$; amount of biomass: $1.0 \mathrm{~g} / \mathrm{L}$ 


\subsection{Kinetic Parameters}

The kinetics of adsorption are critical from the view point that they control process efficiency [13]. Therefore, kinetic models were used to test the experimental data in order to evaluate the controlling mechanism of the biosorption process. The kinetics of $\mathrm{Cr}(\mathrm{VI})$ adsorption onto dried biomass of Pseudomonas aeruginosa ANSC were determined with three different kinetic models i.e. Pseudo first-, second-order and intra-particle diffusion models. The first-order rate equation of Lagergren is one of the most widely used equations for the sorption of solute from a liquid solution $[15,16]$.

$$
\log \left(\frac{q e q}{q e q-q t}\right)=k 1 \cdot \frac{t}{2.303}
$$

where $k_{1}$ is the rate constant of pseudo-first-order adsorption $\left(\mathrm{min}^{-1}\right)$, and $q_{\mathrm{eq}}$ and $q_{\mathrm{t}}$ denote the amount of adsorption at equilibrium and at time $t(\mathrm{mg} / \mathrm{g})$, respectively. The slopes and intercepts of plots of $\log \left(q_{\mathrm{eq}}-q_{\mathrm{t}}\right)$ versus $t$ were used to determine the pseudo first-order rate constant $k_{1}$ and $q_{\mathrm{e}}$.

Additionally, pseudo-second-order equation based on sorption equilibrium capacity may be expressed in this form [16]:

$$
\frac{1}{q t}=\frac{1}{k 2 q e q t}+\frac{1}{q e q}
$$

where $k_{2} \quad(\mathrm{~g} /(\mathrm{mg} \cdot \mathrm{min}))$ is the rate constant of pseudo-second-order adsorption. The rate constant $\left(k_{2}\right)$ and adsorption at equilibrium $\left(q_{\mathrm{eq}}\right)$ can be obtained from the intercept and slope, respectively. The pseudo-second order model is based on the assumption that the rate-determining step may be a chemical sorption involving valence forces through sharing or exchange of electrons between adsorbent and sorbate [16].

According to experimental and theoretical kinetic data in Table 2, adsorption of hexavalent chromium onto dried biomass of $P$. aeruginosa ANSC at optimum conditions of $\mathrm{pH}$, contact time and dose of adsorbent were found to comply with the Pseudo-second order kinetic. Theoretical $q_{\mathrm{eq}}$ values parameterised from the first-order kinetic model gave significant different values compared to the experimental values. The results showed that the first-order kinetic model did not fit the sorption system. However, in the case of the second-order kinetic, the theoretical $q_{\mathrm{eq}}$ values for the dried biomass of $P$. aeruginosa ANSC were in close proximity to the experimental $q_{\mathrm{eq}}$ values. The correlation coefficients for the linear plots of $1 / q_{\mathrm{t}}$ against $1 / t$ for the second-order equation are greater than 0.4 . The pseudo-second-order equation at different temperature levels relatively fitted well with the experimental data for hexavalent chromium (Table 2).

To assess the extent of the diffusion process for adsorption of hexavalent chromium onto dried biomass of strain $P$. aeruginosa ANSC, evaluations were made to ascertain the diffusion coefficients. The intra-particle diffusion model was proposed by Weber and Morris [17]. By linearisation of the curve $q=f\left(\mathrm{t}^{0.5}\right)$, the initial rate of intra-particle diffusion is calculated as:

$$
q=k_{\mathrm{id}} \cdot t^{0.5}
$$

where $q(\mathrm{mg} / \mathrm{g})$ is the amount of adsorbed $\mathrm{Cr}(\mathrm{VI})$ on the dried biomass of $P$. aeruginosa ANSC at time $t$ (min), and $k_{\text {id }}$ is the diffusion coefficient in the adsorbent $\left(\mathrm{mg} / \mathrm{g} \cdot \mathrm{min}^{0.5}\right) \cdot k_{\text {id }}$ has been determined by a plot $q=f\left(\mathrm{t}^{0.5}\right)$.

It is assumed that $\mathrm{Cr}(\mathrm{VI})$ ions are transported into the cell of the adsorbent by intra-particle transport mechanism when the $\mathrm{Cr}(\mathrm{VI})$ sample solution is stirred. The intra-particle transport through this mechanism is meant to be the rate-controlling step. However, it can be said that the amount of adsorbed $\mathrm{Cr}(\mathrm{VI})$ species varies proportionately with the retention time of the adsorbent. The results indicated that the representation in Figure 8 was not linear over the whole-time range for all plots. Although the representations showed similar general contours (i.e. an initial linear portion followed by a climax). The initial linear portion can be attributed to the intra-particle diffusion. However, such a digression of the straight line from the origin could likely be due to the difference in the rate of boundary layer diffusion in the initial stage of adsorption [13]. The intercept of the plot of $q_{\mathrm{t}} v s . t^{0.5}$ generally provides an insight about thickness of boundary layer, as the larger the value of the intercept, the greater the boundary layer diffusion effect is, and vice versa [13]. The values of intra-particle diffusion rate constant, $k_{\text {id }}$, are presented in Table 2 . These results reveal that the $\mathrm{Cr}(\mathrm{VI})$ ions diffused steadily and slowly among the adsorbents at the onset of the adsorption process, and then intra-particle diffusion decreased steadily and stabilised eventually. If the regression of $q v s . t^{0.5}$ is linear and crosses through the point of origin, then intra-particle diffusion is the singular rate-limiting step. However, the digression of the straight lines from the point of origin indicates that intra-particle transport is not the

\begin{tabular}{|c|c|c|c|c|c|c|c|c|c|}
\hline \multirow{2}{*}{ Metal } & \multirow{2}{*}{ Temp (K) } & \multirow{2}{*}{$q_{\mathrm{eq}} \exp (\mathrm{mg} / \mathrm{g})$} & \multicolumn{2}{|c|}{ Pseudo-first order } & \multicolumn{3}{|c|}{ Pseudo-second order } & \multicolumn{2}{|c|}{ Intra-particle diffusion } \\
\hline & & & $K_{1}\left(\min ^{-1}\right)$ & $\mathrm{q}_{\mathrm{eq}}(\mathrm{mg} / \mathrm{g})$ & $\mathbf{R}^{2}$ & $\mathrm{~K}_{2}(\mathrm{~g} /(\mathrm{mg} \cdot \min )$ & $\mathrm{q}_{\mathrm{eq}}(\mathrm{mg} / \mathrm{g})$ & $\mathbf{R}^{2}$ & $K_{\text {id }} \mathrm{mg} /\left(\mathrm{g} \cdot \mathrm{min}^{0.5}\right)$ \\
\hline \multirow[t]{4}{*}{$\mathrm{Cr}(\mathrm{VI})$} & 333 & 0.0294 & -37.671 & -1.278 & 0.2764 & 2.524 & 0.0219 & 0.916 & 0.00350 \\
\hline & 323 & 0.0246 & -37.989 & -1.355 & 0.333 & -8.085 & 0.0198 & 0.939 & 0.00289 \\
\hline & 313 & 0.0201 & -89.770 & -1.605 & 0.2764 & 4.271 & 0.0123 & 0.934 & 0.00217 \\
\hline & 303 & 0.0138 & -77.088 & -1.754 & 0.4284 & -12.866 & 0.0122 & 0.938 & 0.00161 \\
\hline
\end{tabular}
rate-limiting step.

Table 2. Pseudo-first- and second-order kinetics and intra-particle diffusion models for adsorption of $\mathrm{Cr}(\mathrm{VI})$ onto $P$. aeruginosa ANSC 


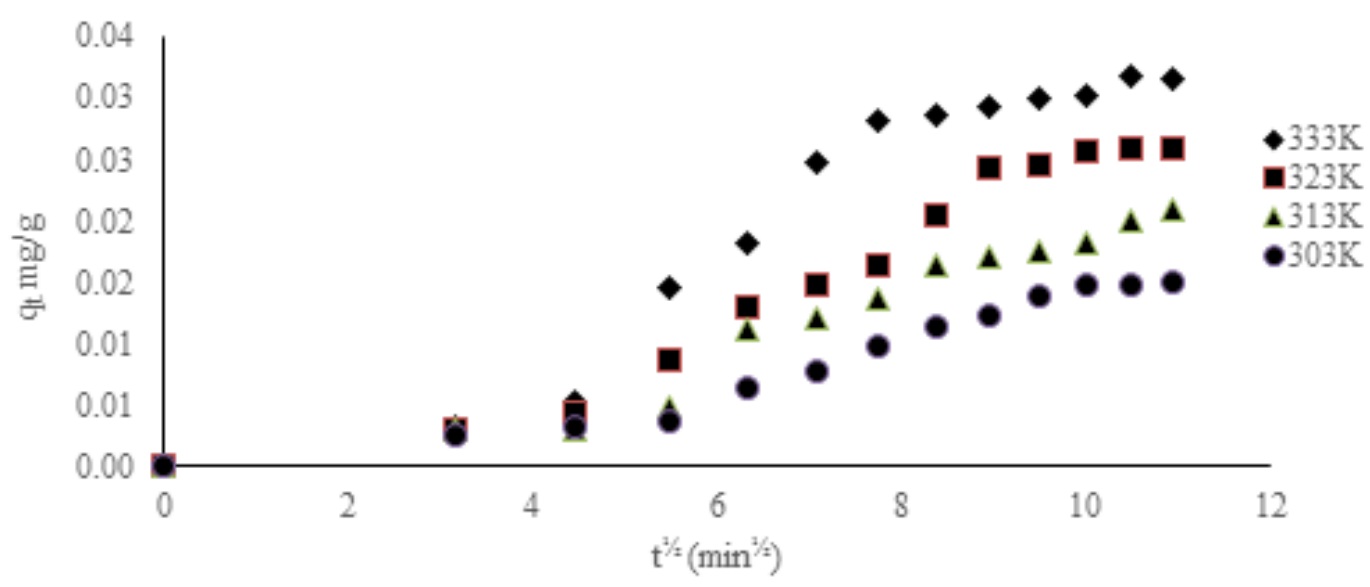

Figure 8. Intra-particle diffusion plot for the adsorption of $\mathrm{Cr}(\mathrm{VI})$ at $333,323,313$, and $303 \mathrm{~K}$

\subsection{Adsorption Isotherms}

Adsorption isotherms are equilibria models used to evaluate the affinity of studied adsorbent (dried biomass of $P$. aeruginosa ANSC) for the removal of $\mathrm{Cr}(\mathrm{VI})$ from aqueous solution. In this present study, two (2) isotherm models (viz. Langmuir and Freundlich models) were used. The Langmuir isotherm model assumes that a monolayer of adsorbate is adsorbed over a uniform adsorbent surface. Hence,

$$
q=\frac{q m \cdot K l \cdot C e}{1+K l \cdot C e}
$$

The constant $K_{\mathrm{L}}$ is related to the energy of adsorption; $C_{\mathrm{e}}$ is the equilibrium concentration of the $\mathrm{Cr}(\mathrm{VI})$ in the solution; $q$ is the amount of adsorbed $\mathrm{Cr}(\mathrm{VI})$ on the adsorbent surface; and the constant $q_{\mathrm{m}}$ represents the maximum binding at the complete saturation of adsorbent binding sites. The essential features of a Langmuir isotherm can be expressed in terms of a dimensionless constant, separation factor or equilibrium parameter, $R_{\mathrm{L}}$, which is used to predict if an adsorption system is "favourable" or "unfavourable" [7].

$$
R l=\frac{1}{1+K l . C o}
$$

The value of $R_{\mathrm{L}}$ indicates the shape of the isotherm to be either unfavourable $\left(R_{\mathrm{L}}>1\right)$ or linear $\left(R_{\mathrm{L}}=1\right)$ or favourable $\left(0<R_{\mathrm{L}}<1\right)$ or irreversible $\left(R_{\mathrm{L}}=0\right)$ [where $C_{\mathrm{o}}(\mathrm{mg} / \mathrm{L})$ is the initial $\mathrm{Cr}(\mathrm{VI})$ concentration].

Freundlich isotherm model, an empirical equation used to describe the adsorption of organic and inorganic compounds on a wide variety of adsorbents, takes into account the fitting of experimental adsorption data from heterogeneous sorbent systems; hence,

$$
\log q e=\log K f+\frac{1}{n} \log C e
$$

where $K_{\mathrm{F}}(\mathrm{L} / \mathrm{mg})$ is an indicator of the multilayer adsorption capacity and $\frac{1}{n}$ is the adsorption intensity, and both indicate the relative distribution of energy and the heterogeneity of the adsorbent sites, respectively [18].

The results showed that the Langmuir model was most suitable for describing the adsorption of hexavalent chromium onto the dried biomass of $P$. aeruginosa ANSC at elevated temperatures of 323 and $333 \mathrm{~K}$ (Table 3). Figures 9 and 10 show the respective fit of both Langmuir and Freundlich models for the adsorption of $\mathrm{Cr}$ (VI) onto $P$. aeruginosa ANSC at 30 to $60^{\circ} \mathrm{C}$. The relative high values of $R^{2}$ in the range of 0.883 to 0.968 indicate minimal deviation from the fitted equation. Also, there exist close proximity of values of modeled $q_{\mathrm{m}}$ with experimental $q_{\mathrm{m}}$. Further, the fact that all $R_{\mathrm{L}}$ values for the adsorption of hexavalent chromium onto dried biomass of $P$. aeruginosa ANSC are approximately unity at 303 to $333 \mathrm{~K}$ for 100 $\mu \mathrm{g} / \mathrm{mL}$ initial $\mathrm{Cr}(\mathrm{VI})$ concentration is a confirmation that the bacterial biosorbent is favourable for adsorption of hexavalent chromium under the studied conditions. Freundlich isotherm model, on the other hand, produced adsorption intensity of greater than unity across studied temperature. 


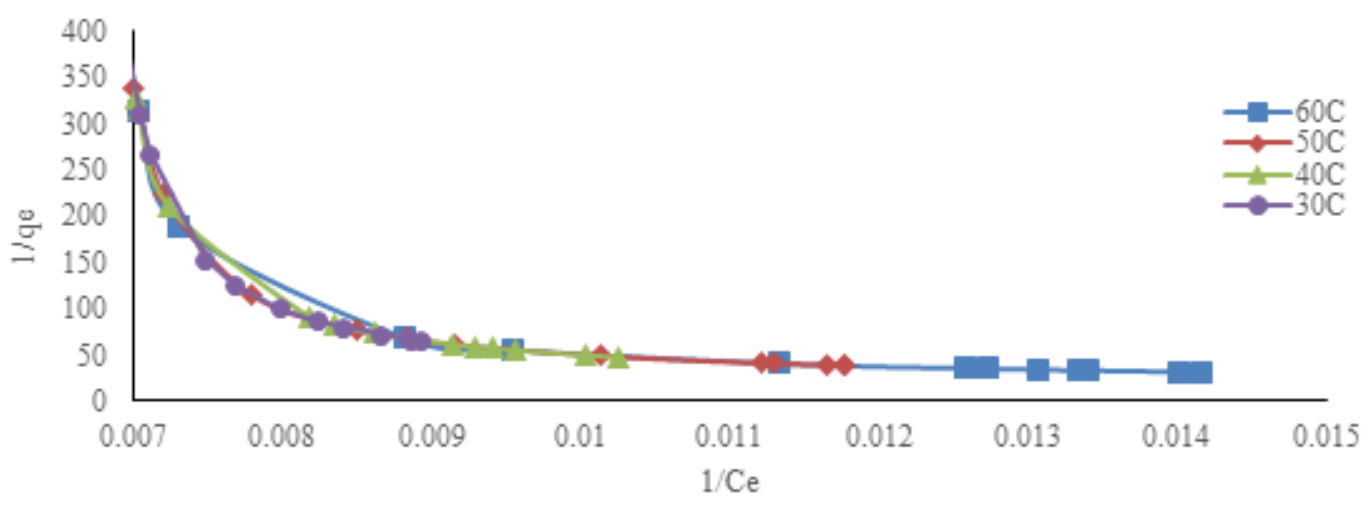

Figure 9. Langmuir adsorption isotherm for chromium (VI)-P. aeruginosa ANSC dried biomass system: temperature $=30-60^{\circ} \mathrm{C} ; \mathrm{pH} 2 ;$ biomass $=$ $1 \mathrm{~g} ;$ time $=2 \mathrm{~h}$

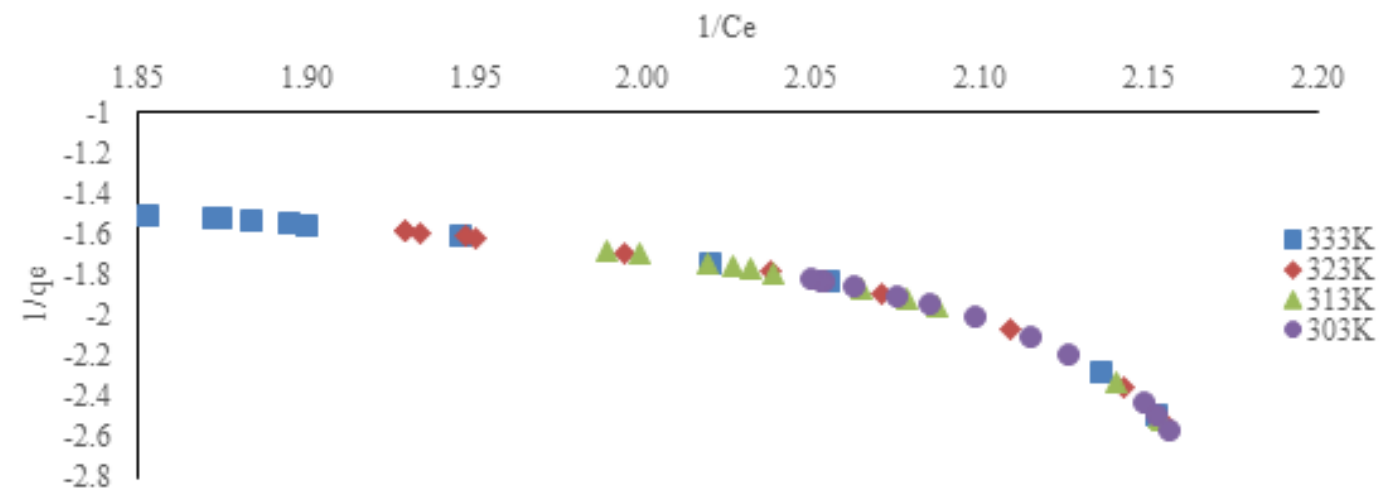

Figure 10. Freundlich adsorption isotherm for chromium (VI)-P. aeruginosa ANSC dried biomass system: temperature $=30-60^{\circ} \mathrm{C}$; $\mathrm{pH} 2$; biomass $=1 \mathrm{~g} ;$ time $=2 \mathrm{~h}$

Table 3. Isotherm model's constants, correlation coefficients and thermodynamics for adsorption of $\mathrm{Cr}(\mathrm{VI})$

\begin{tabular}{|c|c|c|c|c|c|c|c|c|c|c|c|}
\hline \multirow{2}{*}{ Metal } & \multirow{2}{*}{ Temp (K) } & \multirow{2}{*}{$q_{\text {exp }}(m g / g)$} & \multicolumn{3}{|c|}{ Freundlich } & \multicolumn{3}{|c|}{ Langmuir } & \multicolumn{3}{|c|}{ Thermodynamics } \\
\hline & & & $1 / n(L / g)$ & $K_{\mathrm{F}} * 10^{4}(\mathrm{mg} / \mathrm{g})$ & $\mathbf{R}^{2}$ & $\mathrm{~K}_{\mathrm{L}} * 10^{3}(\mathrm{~L} / \mathrm{mg})$ & $\mathrm{q}_{\mathrm{m}} * 10^{3}(\mathrm{mg} / \mathrm{g})$ & $\mathbf{R}^{2}$ & $\Delta \mathrm{G}^{\circ}(\mathrm{kJ} / \mathrm{mol})$ & $\Delta H^{\circ}(\mathbf{k j} / \mathrm{mol})$ & $\Delta \mathrm{S}^{\circ}(\mathrm{j} / \mathbf{k} / \mathbf{m o l})$ \\
\hline \multirow[t]{4}{*}{$\mathrm{Cr}(\mathrm{VI})$} & 333 & 0.0294 & -2.86 & 0.75 & 0.988 & 0.0367 & 2.59 & 0.883 & -28.27 & \multirow{4}{*}{5.43} & \multirow{4}{*}{-6.12} \\
\hline & 323 & 0.0246 & -3.52 & 18.97 & 0.989 & 0.0248 & 2.06 & 0.896 & -28.47 & & \\
\hline & 313 & 0.0201 & -5.10 & 37790 & 0.930 & 0.0123 & 1.21 & 0.956 & -29.41 & & \\
\hline & 303 & 0.0138 & -6.59 & 55118215 & 0.947 & 0.0077 & 0.84 & 0.968 & -29.65 & & \\
\hline
\end{tabular}

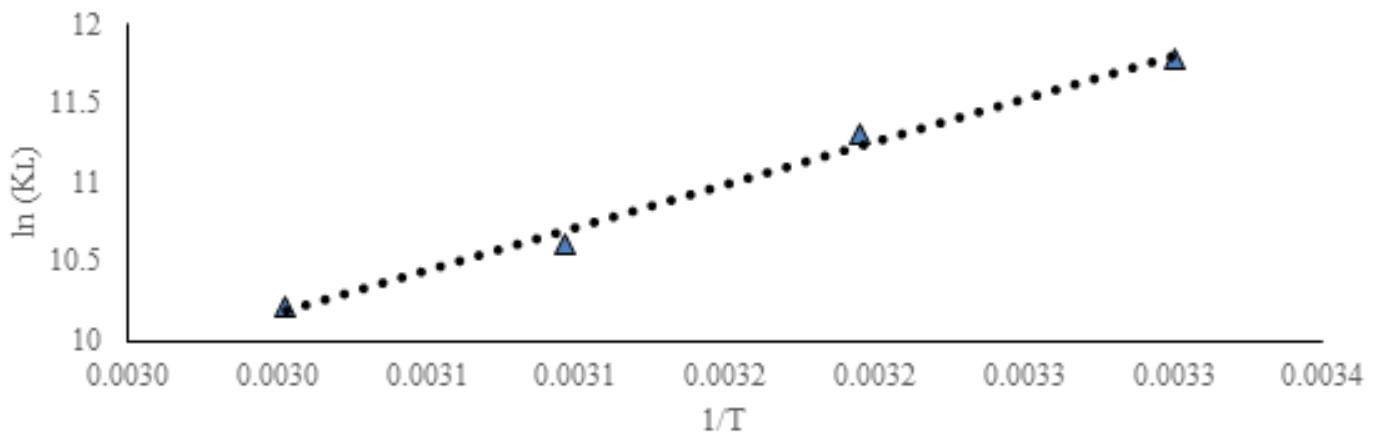

Figure 11. Thermodynamic study of adsorption of $\mathrm{Cr}(\mathrm{VI})$ onto $P$. aeruginosa ANSC biomass

\subsection{Thermodynamic Parameters}

It has been evidenced that the adsorption capacity of the bacterial biosorbent increases with increasing temperature levels; thereby, indicating an endothermic adsorption process. Therefore, in order to assess the feasibility and efficiency of effect of temperature for hexavalent chromium adsorption onto the bacterial biosorbent, thermodynamic parameters of standard Gibbs free energy $\left(\Delta G^{\circ}\right)$, enthalpy $\left(\Delta H^{\circ}\right)$, and entropy $\left(\Delta S^{\circ}\right)$ changes needed 
to be derived. The Gibbs free energy change of the adsorption process was calculated using the following equation:

$$
\Delta G^{\circ}=-R T \ln K l
$$

where $K_{\mathrm{L}}$ is the dependency of the equilibrium association constant from Langmuir isotherm models; $T$, solution's absolute temperature, and $R$, universal gas constant (8.314 $\mathrm{kJ} / \mathrm{mol} . \mathrm{K})$. Applying the above equation resulted in negative values of $\Delta G^{\circ}$; thereby indicating the spontaneity of adsorption process under the conditions studied (Table $3)$. Further, the changes with temperature of the free energy change and the equilibrium constant were represented as follows;

$$
\Delta G^{\circ}=\Delta H^{\circ}-T \Delta S^{\circ}
$$

where values of $\Delta H^{\circ}$ and $\Delta S^{\circ}$ can be calculated from the slope and intercept of the plot between $\ln K_{\mathrm{L}}$ versus $\frac{1}{T}$ [7] (Figure 11). The positive value of $\Delta H^{\circ}$ reveals the adsorption is endothermic and physical in nature (Table 3 ). However, the negative $\Delta S^{\circ}$ value of $\mathrm{Cr}(\mathrm{VI})$ adsorption process onto $P$. aeruginosa ANSC indicates a rather regular increase of randomness at the biosorbent-solution interface during adsorption.

Therefore, in this study, Pseudomonas aeruginosa ANSC has been evidenced to reduce hexavalent chromium using its free cells, and $\mathrm{Cr}(\mathrm{VI})$ reduction by the strain is growth-associated. Also, efficiency for adsorption of hexavalent chromium in aqueous solution by the strain has been enhanced by cell permeabilisation. The adsorption process for hexavalent chromium has been better described by the pseudo-second order kinetic and Langmuir isotherm model. The sorption system was also found to be endothermic and spontaneous.

\section{Conflicts of Interest}

The authors hereby declare no conflict of interest as it regards the publication of this study.

\section{REFERENCES}

[1] Sinha S. N. and Paul D. (2014) Biodegradation potential of some bacterial strains isolated from sewage water. International Journal of Environmental Biology 4(2):107-111

[2] Demirbas A. (2008) Heavy metal adsorption onto agro-based waste materials: a review. Journal of Hazard Mater 157:220-229

[3] Ahemad M. (2014) Bacterial mechanisms for $\mathrm{Cr}(\mathrm{VI})$ resistance and reduction: an overview and recent advances. Folia Microbiol 59:321-332
[4] Zhang Z., Schwartz S., Wagner L. and Miller W. (2000) A greedy algorithm for aligning DNA sequences. Journal of Computational Biology 7(1-2):203-214.

[5] Bartlett R. J. and James B. R. (1996) Chromium. In: Sparks DL (ed) Methods of soil analysis: part 3. SSSA, Madison, New York, pp. 683-701.

[6] Acosta-Rodríguez I., Arévalo-Rangel D. L., Cárdenas-González J. F., Moctezuma-Zárate M. and Martínez-Juárez V. M. (2015) Hexavalent chromium (VI) removal by Penicillium sp. IA-01. Journal of Advanced Bioremediation and Wastewater Pollution 8:165-192.

[7] Elmorsi T. M. (2011) Equilibrium isotherms and kinetic studies of removal of methylene blue dye by adsorption onto miswak leaves as a natural adsorbent. Journal of Environmental Protection 2:817-827

[8] Camargo F. A. O, Bento F. M, Okeke B. C. and Frankenberger W. T. (2003) Chromate reduction by chromium-resistant bacteria isolated from soils contaminated with dichromate. Journal of Environmental Quality 32:1228-1233.

[9] Polti M. A, Amoroso M. J and Abate C. M. (2010) Chromate reductase activity in Streptomyces sp. MC1. Journal of General Applied Microbiology 56:11-18.

[10] Dey S. and Paul A. K. (2012) Optimization of chromate reduction by whole cells of Arthrobacter sp. SUK 1205 isolated from metalliferous chromite mine environment. Geomaterials 2:73-81

[11] Pattanapipitpaisal P., Brown N. L and Macaskie L. E. (2001) Chromate reduction by Microbacterium liquefaciens immobilized in polyvinyl alcohol. Biotechnology Letter 23(1):61-65.

[12] Pal A. and Paul A. K. (2004) Aerobic chromate reduction by chromium-resistant bacteria isolated from serpentine soil. Microbiological Research 159(4):347-354.

[13] Bayramoglu G., Altintas B. and Arica M. Y. (2009) Adsorption kinetics and thermodynamic parameters of cationic dyes from aqueous solutions by using a new strong cation-exchange resin. Journal of Chemical Engineering $152: 339-346$

[14] Al-Sou'od K. (2012) Kinetics of the adsorption of hexavalent chromium from aqueous solutions on low cost material. African Journal of Pure Applied Chemistry 6(14):190-197.

[15] Lagergren S. (1989) Zur theorie der sogenannten adsorption gelöster stoffe, kungligasvenska vetenskapsakademiens handlingar 24:1-39

[16] Ho Y. S (2006) Second-order kinetic model for the sorption of cadmium onto tree fern: a comparison of linear and non-linear methods. Water Research 40:119-125.

[17] Weber J. W. J.and Morriss J. C. (1963) Kinetics of adsorption on carbon from solution. J Sanit Eng Div 89:3160.

[18] Arica M. Y. and Bayramoglu G. (2007) Biosorption of reactive red-120 dye from aqueous solution by native and modified fungus biomass preparations of Lentinus sajorcaju, Journal of Hazard Mater 149:499-507. 